\title{
FIRST RECORD OF NEOCYPHOLAELAPS APICOLA FROM BEEHIVES IN HUNGARY (ACARI: MESOSTIGMATA: AMEROSEIIDAE): RE-DESCRIPTION AND DNA BARCODING
}

\author{
Jenô Kontschán, István Tóbiás, Gábor Bozsik and Gábor Szőcs \\ Plant Protection Institute, Centre for Agricultural Research, Hungarian Academy of Sciences \\ H-1525 Budapest, P.O. Box 102, Hungary; E-mail: kontschan.jeno@agrar.mta.hu
}

Following the first incident in Belgium, the second European record of the honeybee hive inhabiting mite, Neocypholaelaps apicola Delfinado-Baker et Baker, 1983, is presented from Budapest, Hungary. In contrast to the original host in Pakistan (Apis cerana indica Fabricius, 1793) and the host in Belgium (Apis mellifera carnica Pollmann, 1879), the Hungarian specimens were associated to Apis mellifera mellifera Linnaeus, 1758. New knowledge about the morphology and the first Genbank sequences (cytochrome oxidase subunit I) are given with new drawings and scanning electron micrographs. Distinguishing characters between the two European Neocypholaelaps species are also presented.

Key words: Acari, Neocypholaelaps apicola, morphology, DNA barcoding, beehive, Hungary.

\section{INTRODUCTION}

The genus Neocypholaelaps contains 22 species, recorded mostly from the tropical areas of the Earth (Moraes \& Narita 2010, NArita et al. 2011, 2013). Although the majority of these species are associated with bees and can be found on the body of bees as well as in hives and nests of the insects, some of these mite species have been collected on Lepidoptera or on trees (Cocos, Areca, Eucalyptus and Spathodea) (BAKer \& Delfinado-Baker 1985). Only two species have been reported from Europe so far. Haragsim et al. (1978) investigated the hive inhabiting mites in the former Czechoslovakia, reporting 37 species, including the first European population of a Neocypholaelaps species, namely N. favus Ishikawa, 1968, originally described from Japan. Subsequently, Fain and Hosseian (2000) reported the first European population of Neocypholaelaps apicola Delfinado-Baker et Baker, 1983, originally described from Pakistan.

In the framework of a recent survey of mites associated with honeybee hives in Hungary, we have observed some unusual mites, identified as N. apicola. Given that the original description of this species does not provide data on some important characters, here we provide a re-description on the bases of the collected females, with additional notes on their morphology, as well as the first Genbank sequence (cytochrome oxidase subunit I) of the species. 


\section{MATERIAL AND METHODS}

Specimens of N. apicola were collected from debris accumulated on the bottom of bee hives from Budapest. The specimens were cleared in lactic acid and examined in half covered cavity slides with a scientific microscope. Scanning micrographs were taken in the Hungarian Natural History Museum, Budapest with a HITACHI SN 2600 scanning electronmicroscope; the specimens investigated were dried in normal temperature for two days and after they were spotter-coated with gold-palladium. Other mite specimens were mounted in Hoyer's medium and deposited in the Soil Zoology Collection of the Hungarian Natural History Museum (HNHM). Illustrations were made with the help of a drawing tube. Measurements are given in micrometers $(\mu \mathrm{m})$, width of idiosoma was taken at the level of coxae IV.

\section{DNA extraction, PCR amplification, cloning and sequencing}

Half body of Neocyholelops apicola was used for DNA extraction and the remaining half was preserved as voucher.

Total genomic DNA was extracted by REDExtract-N-Ampl ${ }^{\mathrm{TM}}$ Seed PCR Kit (Sigma) following the manufacturer instructions: the insect tissue was covered by $25 \mu \mathrm{l}$ of extraction solution and incubated at $55^{\circ} \mathrm{C}$ for 10 minutes, and 3 minutes at $95^{\circ} \mathrm{C}$. Then, the same volume $(25 \mu \mathrm{l})$ of neutralization solution was added to the sample and mixed by vortexing. One microliter of this mixture was used as DNA matrix in the PCR. Amplification was performed in a $50 \mu \mathrm{L}$ volume containing the PCR buffer $(10 \mathrm{mM}$ Tris- $\mathrm{HCl}, \mathrm{pH} 9.5,2.5 \mathrm{mM}$ $\mathrm{MgCl}_{2}, 50 \mathrm{mM} \mathrm{KCl}, 0.1 \%$ Triton X100), 100 ng each of dATP, dCTP, dGTP and dTTP, 0.1 $\mathrm{nM}$ of each sense and antisense primers and $5 \mathrm{U}$ Taq polymerase (Invitrogen). COI universal primers LCO1490 (5'-ggtcaacaaatcataaagatattgg. $\left.3^{\prime}\right)$ and HCO2198 (5'-taaacttcagggtgaccaaaaaatca-3') (Folmer et al. 1994) were used to amplify the COI fragment.

Thirty-five PCR cycles were performed (Eppendorf Mastercycler gradient) with the following parameters: initial denaturation at $95^{\circ} \mathrm{C}$ for $4 \mathrm{~min}$; denaturation at $94^{\circ} \mathrm{C}$ for $60 \mathrm{~s}$, hybridization at $51^{\circ} \mathrm{C}$ for $60 \mathrm{~s}$ and elongation at $70^{\circ} \mathrm{C}$ for $90 \mathrm{~s}$; final extension at $70^{\circ} \mathrm{C}$ for $7 \mathrm{~min}$. PCR product was purified by High Pure PCR Product Purification Kit (Roche) observed in a BioDoc-It ${ }^{\mathrm{TM}}$ system (UV Transilluminator, UVP, USA) after electrophoresis in a $1 \%$ agarose gel, and subsequently cloned into CloneJet (Thermo Science) according to manufacturer instructions. The recombinant plasmid was transformed into Escherichia coli DH5 $\alpha$ cells. All cloning steps were based upon standard molecular biology protocols (SАмвrоок et al. 1989). Clone containing the expected insert were sequenced by BAYGEN (Szeged, Hungary).

\section{RESULTS}

\section{Neocypholaelaps apicola Delfinado-Baker et Baker, 1983}

$$
\text { (Figs 1-19) }
$$

Neocypholaelaps apicola Delfinado-BAKer \& BAKer, 1983: 2-6, Figs 1-8.

Neocypholaelaps apicola: Fain \& Hosseinian (2000): 33, Moraes \& Narita (2010): 43.

Material examined - Four females (HNHM two on slides in Hoyer's medium, two on aluminum tube covered by gold-palladium). Hungary, Budapest, bee-hives, 09.XI.2014. coll. G. Szőcs. 

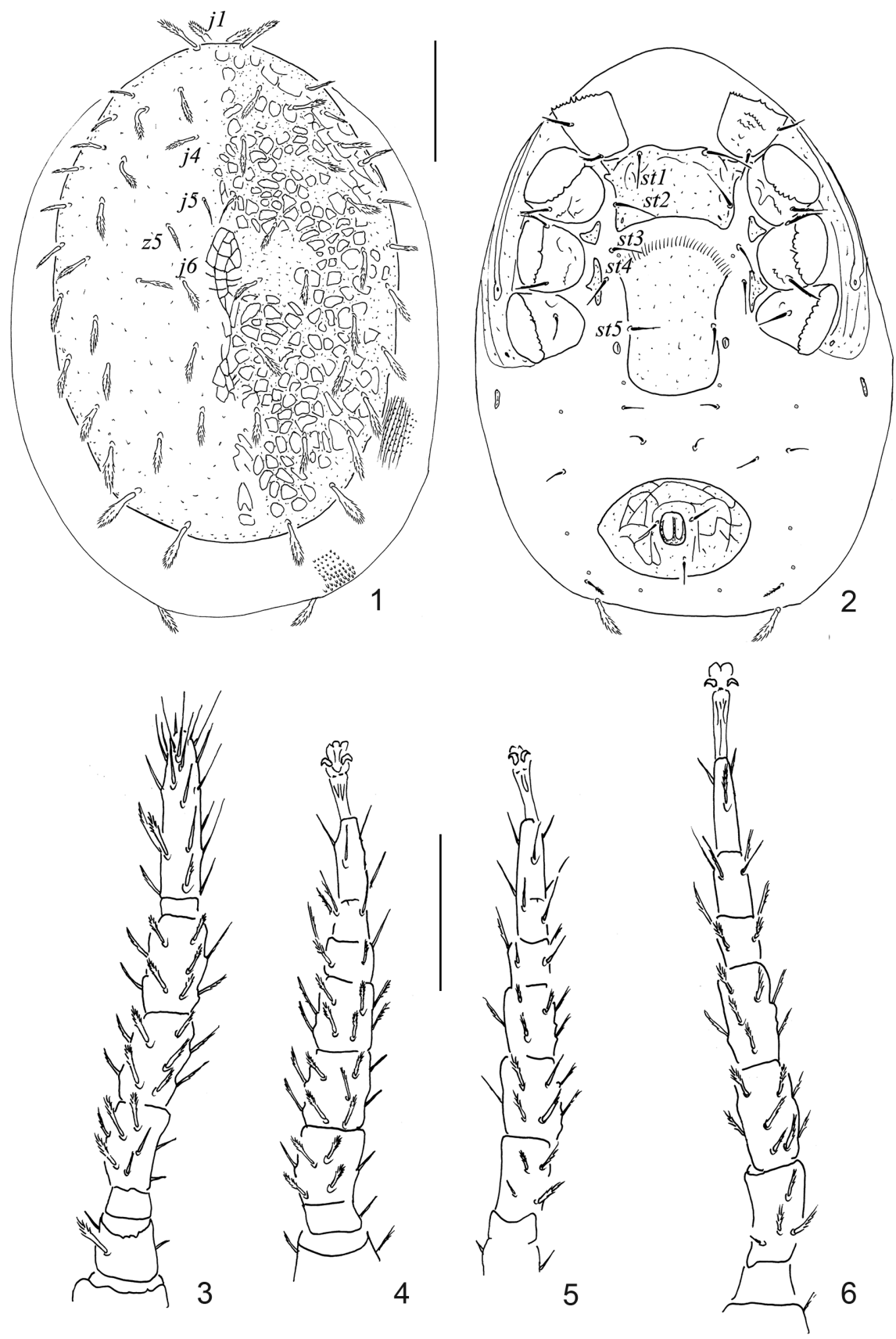

Figs 1-6. Neocypholaelaps apicola Delfinado-Baker et Baker, 1983: 1 = body in dorsal view, 2 = body in ventral view, 3 = leg I in dorsal view (ambulacra and claws not illustrated), $4=$ leg II in dorsal view, 5 = leg III in dorsal view, 6 = leg IV in dorsal view. Scale bars: $100 \mu \mathrm{m}$. 
Diagnosis (based on female) - Dorsal shield covered by irregular pits, with 29 pairs dorsal setae; $j 5$ very short and finely serrate; $j 4, j 6$ and $z 5$ shorter than other dorsal shield setae. Setae $j 1$ more robust than others. Femora I with 11 setae.

Description of females - Idiosoma oval shaped, length 460-470, width 320-330, live females whitish-yellow.

Dorsal idiosoma (Figs 1 \& 11). Dorsal shield covering almost whole dorsal idiosoma. Dorsal shield length 430-440, width 270-280, oval, cuticle covered by irregular pits, with 29 pair of setae. Setae $j 1$ long (26-27), robust and serrate (Fig. 13); majority of dorsal setae long (30-34), serrate and mace-like (Figs 15-16); 5 very short (9-10), needle-like with finely serrate margins; $j 4, j 6$ and $z 5$ (18-20) more robust, short and with serrate margins (Fig. 12). Membranous cuticle surrounding dorsal shield with granulated pattern (Fig. 14).

Ventral idiosoma (Fig. 2). Tritosternum with narrow base, tritosternal laciniae divided into two long and pilose branches. Length of sternal shield in central area 53-55, width 96-98. Two pairs of setae situated on sternal shield, st1 26-28, st2 30-31. Setae st3 and st4 (26-28) situated on membranous cuticle at level of coxae III, a lyrifissure placed close to setae st3. Endopodal shields subtriangular. Epigynal shield linguliform (full length 128-130; 67-69 wide at level of st5) smooth, setae st5 25-28. Metapodal platelets elongate, lightly sclerotized (15-17 × 3-5). Peritrematic plate long, extending posteriorly to level of hind margin of coxa IV, with scant longitudinal striae, free posteriorly, anteriorly fused to dorsal shield, bearing one gland pore close to coxa IV, peritreme extending to level of anterior margin of coxa I. Anal shield (Fig. 17) oval, wider than long (length 63-65 × width 125-127),
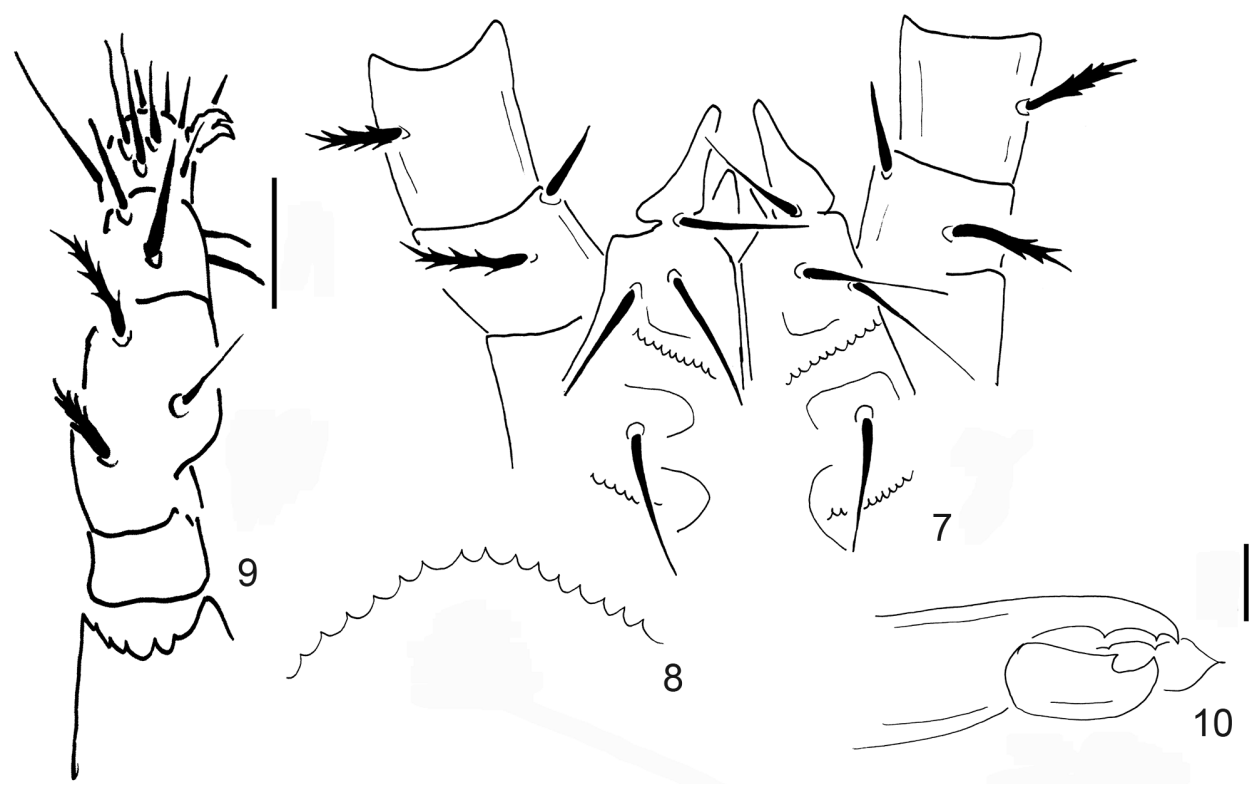

Figs 7-10. Neocypholaelaps apicola Delfinado-Baker et Baker, 1983: 7 = Hypostome and first two free segments of palps in ventral view, $8=$ gnathotectum, $9=$ palp in dorsal view, $10=$ chelicera in lateral view. Scale bars: $20 \mu \mathrm{m}$. 

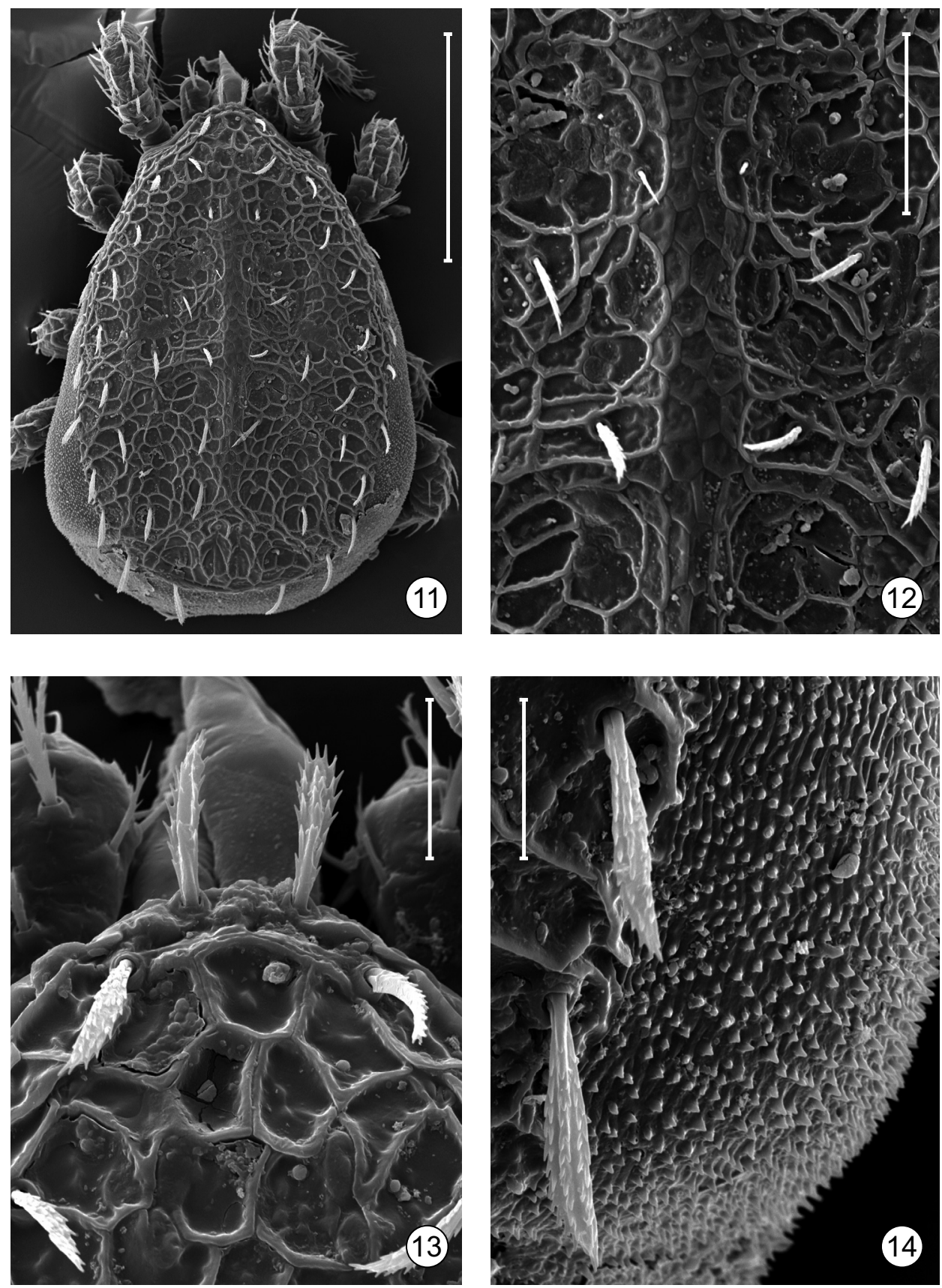

Figs 11-14. Scanning electron micrographs about Neocypholaelaps apicola Delfinado-Baker et Baker, 1983: 11 = body in dorsal view, 12 = area of setae j4, 13 = anterior area of dorsal shield, $14=$ membranous cuticle on posterior part of dorsal body. 
shield with reticulate. Post-anal seta (27-30) as long as para-anal setae; sigillae absent. Soft cuticle with four pairs of smooth and needle-like setae (16-18) anterior to anal shield. One pair of short and finely serrate setae situated at level of posterior margin of anal shield and one pair of wide and marginally serrate setae placed close to the caudal margin of ventral idiosoma. One large gland pore situated on soft cuticle close to setae st5; five pairs of small pores situated on membranous cuticle.
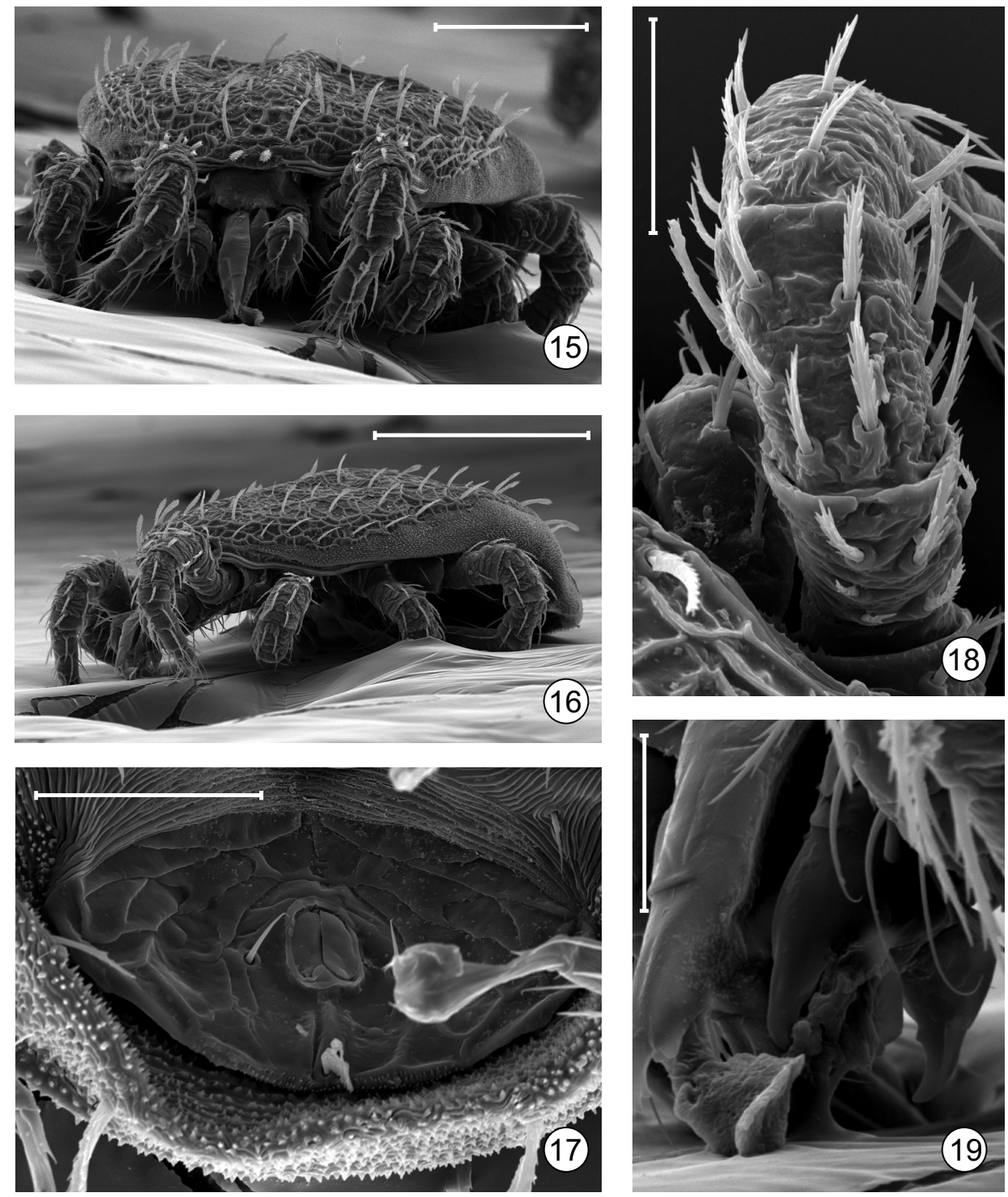

Figs 15-19. Scanning electron micrographs about Neocypholaelaps apicola Delfinado-Baker et Baker, 1983: 15 = body in front view, 16 = body in lateral view, 17 = anal shield, 18 = setation of leg I in dorsal view, 19 = lateral view of chelicerae. 
Table 1. Distinguishing characteristics between the two Neocypholaelaps species reported from Europe.

\begin{tabular}{|c|c|c|}
\hline & N. favus Ishikawa, 1968 & $\begin{array}{c}\text { N. apicola Delfinado-Baker et } \\
\text { Baker, } 1983\end{array}$ \\
\hline Setae j1 & $\begin{array}{l}\text { similar in shape and length to } \\
\text { other dorsal setae }\end{array}$ & $\begin{array}{l}\text { more robust and shorter than } \\
\text { other dorsal setae }\end{array}$ \\
\hline Setae j5 & serrate & needle-like \\
\hline Setae $\mathrm{j} 4, \mathrm{j} 6$ and $\mathrm{z} 5$ & $\begin{array}{l}\text { similar in shape and length to } \\
\text { other dorsal setae }\end{array}$ & $\begin{array}{l}\text { narrower than other dorsal } \\
\text { setae }\end{array}$ \\
\hline $\begin{array}{l}\text { Majority of the } \\
\text { setae on legs }\end{array}$ & $\begin{array}{l}\text { smooth and needle-like with } \\
\text { some serrate setae }\end{array}$ & $\begin{array}{l}\text { serrate with some needle-like } \\
\text { and smooth setae }\end{array}$ \\
\hline
\end{tabular}

Gnathosoma. Gnathotectum rounded with serrate anterior margin (Fig. 8); subcapitulum (Fig. 7) with two pairs of lateral, diagonal rows of denticles; corniculi tapered; internal malae not detectable or perhaps absent; hypostomal setae needle-like, smooth (length: 18-20).

Palps (Fig. 9) with simple and serrate setae; setation of palp segments from trochanter to genua: 2-4-6; palp tarsal claw two-tined, with tines tapered. Chelicerae (Figs 10 \& 19) short; fixed digit with two teeth and with a membranous cheliceral lobe; movable digit with one tooth.

Legs (Figs 3-6). Lengths of legs (excluding ambulacra) 360-400. All tarsi with ambulacrum and claws. Setation of leg segments I-IV: coxae 2-2-2-1; trochanters 6-5-5-5, femora 12-9-6-6 (1-2/3,1/3-2; 1-2/2,1/2-1 0-2/2,1/1-0; 0-1/2,1/1-1), genua 12-11-9-9 (2$2 / 3,3 / 0-2 ; 2-2 / 3,2 / 0-2 ; 1-2 / 2,2 / 0-2 ; 1-2 / 3,1 /-2)$, tibiae $12-10-8-9$ (2-2/3,3/0-2; 2-2/2,2/0-2; $1-2 / 1,2 / 0-2 ; 1-2 / 2,2 / 0-2)$, tarsi 31-16-16-16 Majority of leg setae serrate, some needle-like (see Figs 3-6 \& 18).

\section{DISCUSSION}

Neocypholaelaps apicola was originally described on specimens collected in hives of A. cerana indica honeybee in Rawalpindi, Pakistan. Later, FAIN and Hosseinian (2000) reported the species for the first time in Europe, from Gent, Belgium associated to Apis mellifera carnica. Up to now, these were the only records of the species. The new occurrence of N. apicola in Hungary is especially surprising, taking into consideration the intensive surveys of honey-bee associated mites in Europe (which mostly concentrate on the Varroa mites), in which, this species had not been previously mentioned from Central Europe.

Another Neocypholaelaps species was reported from Europe by Haragsim et al. (1978), namely Neocypholaelaps favus Ishikawa, 1968, found in Jablonec nad Nisou and Veseli nad Moravou, in the former Czechoslovakia (now Czech Republic). N. favus was originally described from Japan. Since both Neocypholaelaps species recorded so far in Europe were originally described from Asia, we suppose that they both were introduced to Europe by transport of bees from that continent. 
Table 2. Neocypholaelaps apicola Delfinado-Baker et Baker, 1983 cytochrome oxidase subunit I (Genbank accession number is KP966315)

\begin{abstract}
GGTCAACAAATCATAAAGATATTGGTACATTATATTTTATTTTTTCAGTTTGAAGAGGATTATTAGGTAGATCTATAAGAGCTCTTATTCGTTTTGAATTAAATCAAAGAGGTTCTCTTTTAAGAAGTGAACAATTATATAATGTTTTAGTTTCTGCTCATGCTTTTATTATAATTTTTTTTATAATTATACCTGCTATAGTAGGTGGTTTTGGAAATTGATTAGTTCCTATTTTTATTTTAGCTCCTGATGTAGCTTTTCCTCGTCTTAATAATATAAGATTTTGATTATTACCTGTTTCTTTATTTTTTCTTGTTATTAGTTCTTTTATCGATGAGGGGATGGGAACGGGTTGAACAGTTTATCCTCCATTATCTTTATATCCTTTTCATAGAGGAATATCTGTAGATTTAGGTATTTTTTCATTACATATTGCTGGTATTTCTCCTATTTTAGGTTCAATTAATTTTATTTGTACTATTATAAATTTACGAAATGATTTAATGAGAATAGAACGGGTTTCTTTGTTTGTTTGATCTATTTTAATTACTGTTATTTTATTGCTATTAAGATTACCAGTTTTAGCTGGTGCTATTACTATATTATTAACTGATCGAAATTTTAATACTTCTTTTTTTGATCCAGTAGGAGGAGGTGATCCTATTTTATATCAACATTTATTTTGATTTTTTGGTCACCCTGAAGTTTA
\end{abstract}

Neocypholaelaps favus is quite similar to N. apicola, therefore we summarize the most important distinguishing characters in Table 1. The chelicera of $N$. apicola bears a membranous cheliceral lobe which suggests that this species feeds mainly on pollen or on nectar (NARITA et al. 2013).

Delfinado-BAKer and BAKer (1983) gave a leg chaetotaxy to the description of the species. We have found differences between the data of DelfinadoBAKER and BAKER (1983) and that of our specimens collected in the present study in Hungary. According to the original description, femora I and IV would have respectively 11 and 5 setae, but we found 12 and 6 setae instead. It is not possible to know which setae were missed by Delfinado-Baker and BAKER (1983), because they presented only the total number of setae on each segment. The shapes of the leg setae are also missing from the original description.

Up to now, sequences of only two unidentified Neocypholaelaps species and Neocypholaelaps ampullula (Berlese, 1910) were available in the Genbank (18 sRNA and 28 sRNA). Here, we present the first cytochrome oxidase subunit I sequence for an identified Neocypholaelaps species (Table 2). Unfortunately we have found only COI sequences of unidentified ameroseiid species in the Genbank, and thus we cannot compare our result with other previously uploaded sequences.

Acknowledgements - This study was financially supported by the Hungarian Ministry of Agriculture, via the Hungarian National Apiary Association (OMME). 


\section{REFERENCES}

Baker, E. W. \& Delfinado-Baker, M. (1985) An unusual new species of Neocypholaelaps (Acari: Ameroseiidae) from the nests of stingless bees (Apidae: Meliponinae). International Journal of Acarology 11(4): 227-232. doi: 10.1080/01647958508683421

Delfinado-Baker. M. \& Baker, E. W. (1983) A new species of Neocypholaelaps (Acari: Ameroseiidae) from brood combs of the Indian honey bee. Apidologie 14(1): 1-7. doi: 10.1051/apido:19830101

De Moraes, G. J. \& Narita, J. P. Z. (2010) Description of a new species of Neocypholaelaps (Acari: Ameroseiidae) from Brazil, with a key to the world species. Zootaxa 2554: $37-44$.

Fain, A. \& Hosseinian, S. H. (2000) Observations sur des acariens (Acari) infestant les ruches de Apis mellifera race carnica (Insecta Apidae) de Belgique. Bulletin S.R.B.E.lK.B. V.E. 136: 32-33.

Folmer, O., Black, M., Hoeh, W., Lutz, R. \& Vrijenhoek, R. (1994) DNA primers for amplification of mitochondrial cytochrom c oxidase subunit I from diverse metazoan invertebrates. Molecular Marine Biology and Biotechnology 3: 294-299.

Haragsim, O., SamšiňaK, K. \& Vobrázková, E. (1978) The mites inhabiting the bee-hives in ČSR. Zeitschrift für Angewandte Entomologie 87: 52-67. doi: 10.1111/j.1439-0418.1978. tb02425.x

IshiKawA, K. (1968) Studies on mesostigmatid mites associated with the insects in Japan. Matsuyama Shinonome Junior College 3: 197-218.

Narita, J. P. Z., de Moraes, G. J. \& Fernando, L. C. P. (2011) Two species of Neocypholaelaps from Sri Lanka (Acari: Ameroseiidae), with description of a new species. Zootaxa 2741: 59-65.

Narita, J. P. Z., Pédelabat, M. \& de Moraes, G. J. (2013) A new species of Neocypholaelaps Vitzthum (Acari: Ameroseiidae), with notes on the cheliceral lobes and ventral porelike stuctures of mites of this family. Zootaxa 3666: 1-15. doi: 10.11646/zootaxa.3666.1.1

Sambrook, J., Fritsch, E. F. \& Maniatis, T. (1989) Molecular cloning. A laboratory manual. Vols 1 \& 2. 2nd ed. Cold Spring Harbor Laboratory, Cold Spring Harbor, New York, $1626 \mathrm{pp}$.

Revised version received March 10, 2015, accepted May 17, 2015, published August 14, 2015 